\title{
Cell structure-impact property relationship of polypropylene/thermoplastic elastomer blend foams
}

\author{
A. Heidari, M. Fasihi* \\ School of Chemical, Petroleum and Gas Engineering, Iran University of Science and Technology, Tehran, Iran
}

Received 6 October 2018; accepted in revised form 13 December 2018

\begin{abstract}
The purpose of the present study was to investigate the effect of cellular structure on the impact strength of polypropylene/polyolefin elastomers blend foams produced by the continuous extrusion process. To create different cell sizes, two chemical blowing agents were employed: azodicarbonamide and sodium bicarbonate. Sodium bicarbonate created foams with bigger cell size and cell wall thickness than azodicarbonamide. The impact strength of the neat and blend foams were studied and correlated to the foam properties and structure. It was observed that the impact strength of blend foams was directly related to the concentration of polyolefin elastomers (POE). Increasing POE by up to $30 \mathrm{wt} \%$ increased the foam impact strength by more than $400 \%$. On the other hand, Increasing POE content caused the cell size and cell wall thickness to be reduced. Moreover, an attempt has been made to establish a relationship between the impact strength and cellular structural parameters. It was found that in the blend foams with higher cell wall thickness the rough fracture of the cell walls was intensified and in turn, the impact strength of the foams improved further.
\end{abstract}

Keywords: polymer blends and alloys, foam, polypropylene, impact strength, thermoplastic elastomer

\section{Introduction}

Nowadays, polymer foams are used in numerous practical fields, such as automobile industry, packaging materials, building materials and sports equipment due to their good mechanical properties, low cost, low weight, energy insulation capability and high energy absorption through bending or fracture of the cell walls [1-4]. The most commonly used thermoplastic foams are based on polystyrene (PS), polyvinyl chloride (PVC), and polyethylene (PE). These foams are easily produced by continuous processes such as extrusion. However, the applications of such products have some limitations [5-8]. Recently, PP foams has been suggested as a substitute for other thermoplastics such as PS and PE foams because of its superior properties, such as higher hardness compared to PE, better impact strength than PS, higher service temperature range than both of them and proper chemical resistance [9-12]. However, its foamability is weak due to its low melt strength, which causes swift rupture of the cell walls during the bubble growth stage [13]. As a result, polypropylene foams are generally high in open cell and have nonuniform cell distribution that is not apt for many applications [13, 14]. To solve this problem, many researchers have tried to modify PP by partially crosslinking PP [15], grafting long side-chains to PP, or combining this polymer with some additives [1619], which greatly improved melt strength [20-22], and in turn, improved melt elasticity [23], and foamability [24]. It has been shown in the foam extrusion process that branched polypropylenes have the potential to accelerate cellular correlation and increase the volume expansion [13, 24, 25].

In addition to creating an applicable foam structure, the resulting foam properties should be optimized 
for specific applications. Among the application of propylene foams are car bumpers and packaging of various electronic parts. In such applications, high impact strength is a vital prerequisite for the foam [26]. But in previous researches, little consideration has been given to improving the impact strength of polypropylene foam. In the case of non-foamed (solid) polypropylene, many studies have been conducted with the aim of improving impact strength. This was usually achieved by adding an elastomer component to the polypropylene. Ethylene propylene rubber (EPR) and ethylene propylene diene monomer (EPDM) have been used as elastomeric phase in a number of studies [27-29]. But the improvement of the impact strength by adding thermosetting elastomers was essentially achieved only through proper dispersion and vulcanization of the rubber phase [30, 31]. Complications associated with the production of such blends, such as multiphase morphology and controlling the process of vulcanization, have led to the extensive use of alternative blends. Further studies in this field have recently highlighted the status of thermoplastic elastomers compared to thermosetting rubbers, which is due to their comparable properties to thermosetting rubbers without the need for the processes of combination and vulcanization [3133]. Over the past decade, polyolefin elastomers (POEs), synthesized by the metallocene catalysts, usually based on polyethylene, polypropylene or their copolymers, are used more often as the rubber phase in the blends. The blending properties of these elastomers with polypropylene have been previously reported in various studies regarding their high capability to increase impact strength [34-36]. It has been reported that the morphology of the propagation of rubber particles inside the polypropylene matrix, as well as the rubber particle size, play the most important role in increasing the impact strength of the compound, to such extent that POEs with proper distribution can enhance the impact strength of the compound by up to 13 times [37].

Various studies have also been conducted on the foamability and morphology of polypropylene/thermoplastic elastomeric foam blends. It has been reported that nucleation of the cell depends on the critical size of the rubber particles and its total surface within the matrix $[38,39]$. Conversely, cell growth depends on the composition of the polymer matrix [40]. Kim et al. [38] proved that the final morphology of polypropylene blend foams is influenced by the size and overall surface area of the dispersed rubber particles. It should be noticed that polypropylene is naturally crystalline, but the thermoplastic elastomers are amorphous or have a very slight crystallinity. Lower crystallinity can lead to greater solubility of gas in the samples [41-43].

Although some studies have been done on polypropylene foam blends, no comparative study so far has been conducted between the type of thermoplastic elastomer and various blowing agents on its effect on morphology and their impact properties. Therefore, in this study, two types of thermoplastic elastomers with different bases, as well as two types of blowing agents in PP foams were compared. Moreover, the main goal, the effect cellular structure on the impact strength of polypropylene blends foams was investigated.

\section{Experimental}

\subsection{Materials}

The PP used in this study were branched homopolymer PP (Daploy W130 HMS, MFI = 2.1 g/10 min at $230^{\circ} \mathrm{C}$ ) supplied by Borealis GmbH (Vienna, Austria). Polyolefin elastomers (POEs) were polypropylene-based (Vistamaxx 6102) from ExxonMobil and ethylene-based (Tafmer DF840) from Mitsui Chem. Vistamaxx 6102 is Isotactic propylene repeat units with random ethylene distribution and Tafmer DF 840 is copolymer of ethylene-alpha olefin both produced using metallocene catalyst technology. Talc (Persitalc 20-SW, average size $=3.5 \mu \mathrm{m}$ ) from Omya Pars Co. (Tehran, Iran) was applied as nucleating agent. Sodium bicarbonate (SB, decomposed over the temperature range of $160 \pm 5^{\circ} \mathrm{C}$ ) from Daejung Co. (Shiheung, South Korea) and activated azodicarbonamide (Porofor ADC) from Haitai Chem Co were used as blowing agents. $\mathrm{SB}$ releases $\mathrm{CO}_{2}$ gas after decomposition, while $\mathrm{ADC}$ releases $\mathrm{N}_{2}$ which has lower solubility in PP than $\mathrm{CO}_{2}$.

\subsection{Preparation of foam samples}

To prepare the foam samples, polypropylene, POE, talc and foaming agent were dry mixed at ambient temperature. The percentage of talc and foaming agent for all samples were 2 and $4 \mathrm{phr}$, respectively. The resulting compound was extruded by a single screw extruder (Kajaran KEX series $D=20 \mathrm{~mm}$, $L / D=26)$. Extruder die was a $4 \mathrm{~mm}$ diameter rod shape. The diameter of the foam rods was between 7 to $10 \mathrm{~mm}$ depending on their expansion ratio. The 
Table 1. Compositions of the description.

\begin{tabular}{|l|c|c|c|c|c|c|}
\hline Samples & $\begin{array}{c}\text { PP } \\
{[\mathbf{w t} \%]}\end{array}$ & $\begin{array}{c}\text { Tafmer } \\
\mathbf{D F 8 4 0} \\
{[\mathbf{w t} \%]}\end{array}$ & $\begin{array}{c}\text { Vistamaxx } \\
\mathbf{6 1 0 2} \\
{[\mathbf{w t} \%]}\end{array}$ & $\begin{array}{c}\text { ADC } \\
\text { [phr] }\end{array}$ & $\begin{array}{c}\text { SB } \\
\text { [phr] }]\end{array}$ & $\begin{array}{c}\text { Talc } \\
{[\mathbf{p h r}]}\end{array}$ \\
\hline P-S & 100 & - & - & - & 4 & 2 \\
\hline PT1-S & 90 & 10 & - & - & 4 & 2 \\
\hline PT2-S & 80 & 20 & - & - & 4 & 2 \\
\hline PT3-S & 70 & 30 & - & - & 4 & 2 \\
\hline PV1-S & 90 & - & 10 & - & 4 & 2 \\
\hline PV2-S & 80 & - & 20 & - & 4 & 2 \\
\hline PV3-S & 70 & - & 30 & - & 4 & 2 \\
\hline P-A & 100 & - & - & 4 & - & 2 \\
\hline PT1-A & 90 & 10 & - & 4 & - & 2 \\
\hline PT2-A & 80 & 20 & - & 4 & - & 2 \\
\hline PT3-A & 70 & 30 & - & 4 & - & 2 \\
\hline PV1-A & 90 & - & 10 & 4 & - & 2 \\
\hline PV2-A & 80 & - & 20 & 4 & - & 2 \\
\hline PV3-A & 70 & - & 30 & 4 & - & 2 \\
\hline & & & & & &
\end{tabular}

extruder temperature profile from feed to die zone was set at $140{ }^{\circ} \mathrm{C} / 200^{\circ} \mathrm{C} / 170^{\circ} \mathrm{C}$, and the screw rotating speed was also maintained fairly constant at $50 \mathrm{rpm}$. Die temperature is adjusted according to previous studies to yield the greatest expansion [44]. The components and their names are included in Table 1 based on their coding ( $\mathrm{P}$ for polypropylene, $\mathrm{S}$ for sodium bicarbonate, $\mathrm{A}$ for azodicarbonamide, $\mathrm{T}$ for Tafmer, $\mathrm{V}$ for Vistamaxx 6102, and numbers 1 , 2, 3 related to the 10,20 and 30 percentage of the POE).

\subsection{Characterizations}

\subsubsection{STA analysis}

To study the decomposition behavior of blowing agents, simultaneous thermal analysis (STA) or TGDSC was performed by STA504 (Bahr, Germany) from ambient temperature to $600^{\circ} \mathrm{C}$ at $10 \mathrm{oC} / \mathrm{min}$ under argon purge.

\subsubsection{Density measurement}

To measure the density of samples, the Archimedes measurement method according to ASTM D792 was applied. The sample was first weighed in air and then in an aquatic environment. Then, using the following equation, the density of the sample was calculated by Eqution (1):
This measurement was reiterated at least three times, and the average of the results was reported as the density of foam. The volume expansion ratio (VER) was calculated by the density ratio of the samples before the foam $\rho_{\mathrm{P}}$ and after the foam $\rho_{\mathrm{f}}$ in Equation (2):

$V E R=\frac{\rho_{\mathrm{P}}}{\rho_{\mathrm{f}}}$

\subsubsection{Microscopic and morphology analysis}

To study the morphology, a Czech scanning electron microscope (SEM, VEGA II TESCAN) was used. To this end, the specimens were first fractured in liquid nitrogen. The samples were then coated with gold for better resolution. The sample surface micrograph was analyzed using Image J software and cell sizes were measured, next. The average size of the foam cells from the samples was obtained from a mean size of at least 50 cells. The average cell size was determined from the data of SEM observation. The function for determining cell density $N_{\mathrm{c}}\left[\mathrm{cell} / \mathrm{cm}^{3}\right]$ is defined in Equation (3) [45]:

$N_{\mathrm{c}}=\frac{10^{4}}{d^{3}}\left[1-\frac{\rho_{\mathrm{P}}}{\rho_{\mathrm{f}}}\right]$

Where $\rho_{\mathrm{P}}$ is the density before foam and $\rho_{\mathrm{f}}$ is the density in foam mode and $d$ is the average cell size $[\mathrm{mm}]$. The cell walls thickness $(\delta)$ was also calculated from the Equation (4) [45]:

$\delta=d\left[\frac{1}{\sqrt{1-\frac{\rho_{\mathrm{P}}}{\rho_{\mathrm{f}}}}}-1\right]$

\subsubsection{Impact test}

The same rods produced by the extruder were directly used for the impact test. For this purpose, at least three of $6 \mathrm{~mm}$ pieces were cut from each sample, and after measuring the mean diameter of each, their impact strength was measured by Charpy impact method using GEOTECH instrument. It should be noticed that our sample shape did not entirely match the Charpy standard (ISO 719) as the cross section of samples in this standard is rectangular. Because it was not possible to mold foam products after extrusion, we

$\rho_{\mathrm{f}}=\frac{\text { Sample weight in the air }}{\text { Sample weight in the air }- \text { Sample weight in the water }}$. Density of water 

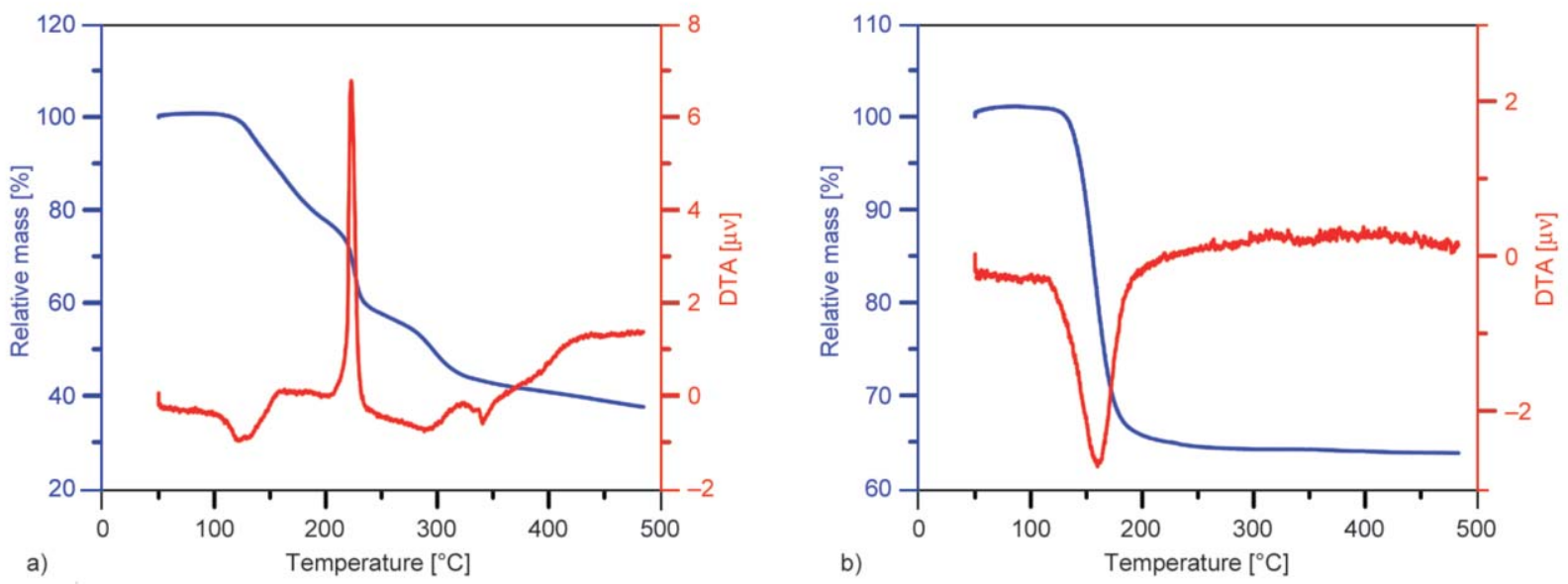

Figure 1.:Thermogravimetry (TG) and differential scanning calorimetry (DSC) thermograms of (a) azodicarbonamide and (b) sodium bicarbonate.

did this test with circular cross section and report the results, comparatively.

\section{Results and discussion}

\subsection{Thermal analysis of blowing agents}

The decomposition reaction of azodicarbonamide (ADC) [46] and sodium bicarbonate (SB) [47] is as follows and the resulting gas are respectively nitrogen in Equation (5) and carbon dioxide in Equation (6):

$$
\begin{aligned}
& \mathrm{C}_{2} \mathrm{H}_{4} \mathrm{~N}_{4} \mathrm{O}_{2} \stackrel{160^{\circ} \mathrm{C}}{\longrightarrow} \mathrm{N}_{2}+2 \mathrm{NH}_{2} \mathrm{CO} \\
& 2 \mathrm{NaHCO}_{3} \stackrel{160^{\circ} \mathrm{C}}{\longrightarrow} \mathrm{Na}_{2} \mathrm{CO}_{3}+\mathrm{H}_{2} \mathrm{O}+\mathrm{CO}_{2}
\end{aligned}
$$

However, some more complicated decomposition reactions were reported for ADC [46].

The STA image of ADC and CB are presented in Figure 1 (exo up). ADC had a three-stage decomposition,

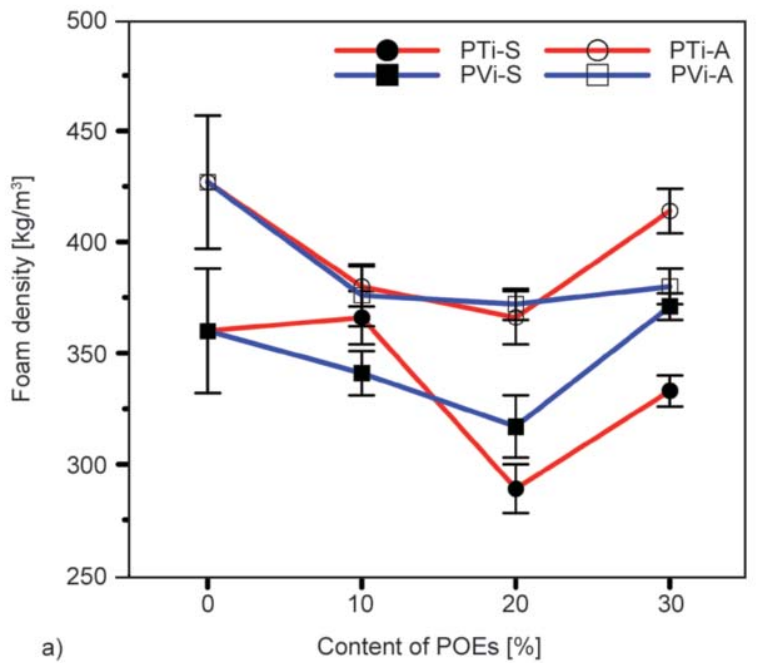

consisted of two endothermic peaks at 129 and $291^{\circ} \mathrm{C}$ and one exothermic peak at $222^{\circ} \mathrm{C}$. The first decomposition stage was in the window of processing temperature (up to $200^{\circ} \mathrm{C}$ ) in which the weight loss of blowing agent was about $26.9 \%$. From the Equation (5) and assumption of ideal gas law, the volume of gas produced per gram of ADC was calculated $231 \mathrm{~cm}^{3}$. For SB, one step endothermic decomposition peak was observed at $160^{\circ} \mathrm{C}$ with drop weight of $33.1 \%$. Similar to ADC, the released gas per gram of SB was calculated which was obtained $254 \mathrm{~cm}^{3}$. So, the volume of gas produced by SB was a little higher than ADC.

\subsection{Density and expansion ratio of foams}

Figure 2 shows the relationship between density and $V E R$ of foam samples based on the type and percentage of POE. The density of neat PP foams for P-A and P-S samples were equal to 427 and $360 \mathrm{~kg} / \mathrm{m}^{3}$,

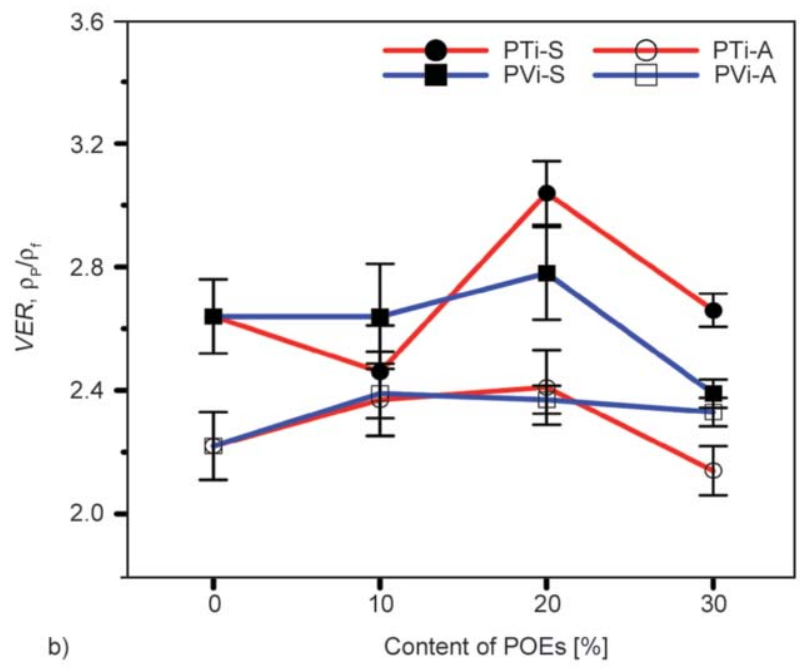

Figure 2. Variation of (a) foam density and (b) VER with POE content at different type of POE. 
resulting in the expansion ratios of 2.20 and 2.64 , respectively.

In all neat and blend samples, the foam produced with sodium bicarbonate had a lower density and a higher expansion ratio than azodicarbonamide with similar POE percentages. From the STA results, the amount of blowing agent was well enough to higher expansion ratio potential. The excess gas that could not dissolve in polymer matrix was expelled from the foam surface. So, the higher expansion ratio of the foams included sodium bicarbonate was due to the higher solubility of $\mathrm{CO}_{2}$ gas in PP compared to $\mathrm{N}_{2}$ [48]. The $V E R$ of the blends foams was in the range of 2.2-3.1. For PT-S foams, the maximum VER was valued approximately at 3.1 for $20 \%$ of $\mathrm{POE}$, which is slightly higher than that of PV-S foams.

In foam samples with sodium bicarbonate as the blowing agent, VER initially reached a maximum value with an increase in the amount of POE to $20 \%$ and decreased thereafter. The initial increase in the VER with increasing POE is probably due to increase of solubility of the gas in the blends by increasing POE [41, 42]. However, a further increase in POE has led to an increase in the amount of gas exhaust from the polymer during expansion (because of lower crystalline phase which is a barrier against gas exhaust), and thus, in the $30 \%$ of POE, the VER has decreased.

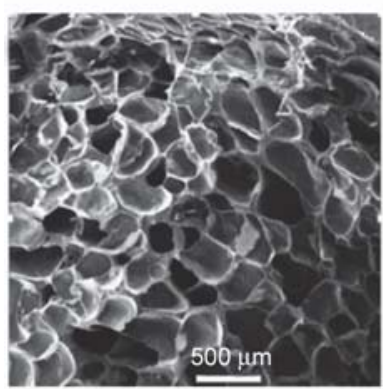

a)

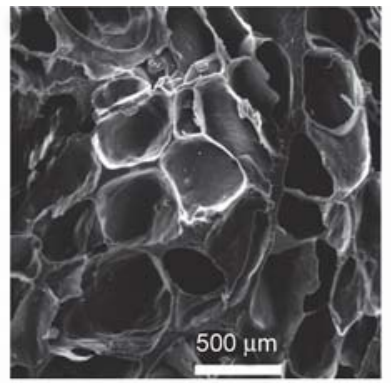

b)

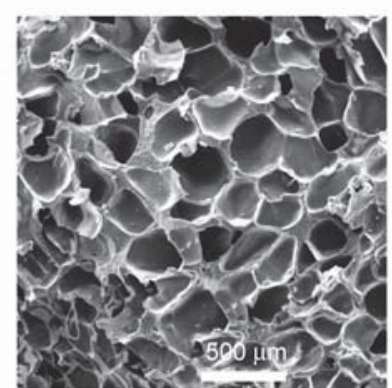

e)

\subsection{Cellular structure of blends foams}

The morphology of the polypropylene foam depends on the gas released by the chemical blowing agent. Figure 3 shows the SEM images of foam samples blend with sodium bicarbonate blowing agent and two types of POE in different percentages. Values for cell size and cell density for samples containing two different types of POE are shown in Figure 4. Generally, it can be stated that cell diameter sizes for samples containing ethylene-based POE at all concentrations were greater than those of polypropylene-based POE. Increasing the concentration of POE resulted in the cell diameter distribution for the PT-S sample to be narrowed, and the mean cell diameter decreased slightly while remaining almost constant for PV-S samples. This difference in cell size in PT-S and PV-S samples has led to differences in cell density of the samples, to such extent that cell density for PV foams has been observed to be almost 3 times that of PT.

For PV samples, cell density first increased with increasing POE concentrations and then reached approximately a constant value. For these samples, the cell diameter was approximately the same and the density of foam had the greatest effect on cell density. Hence, the maximum cell density has occurred at the minimum foam densities for the PV2-S sample. However, for PT-S samples, cell density has been

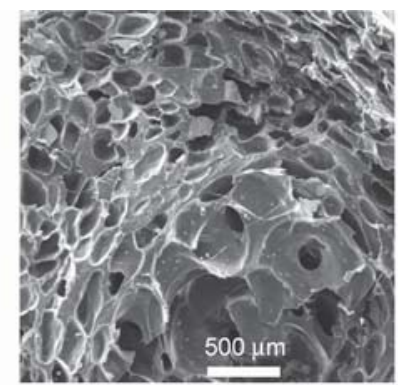

c)

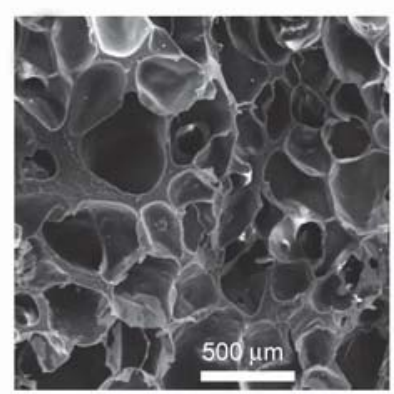

f)

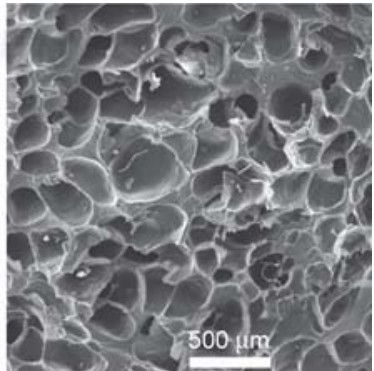

d)

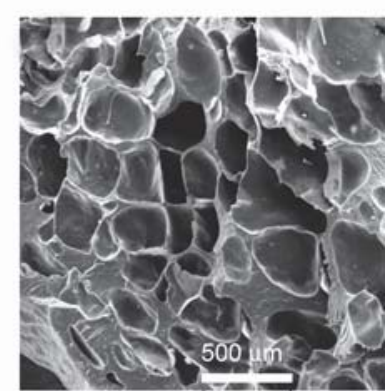

g)

Figure 3. SEM micrographs of fractured surfaces of PP/POE-S Foams; (a) P-S, (b) PT1-S, (c) PT2-S, (d) PT3-S, (e) PV1S, (f) PV2-S and (g) PV3-S. 

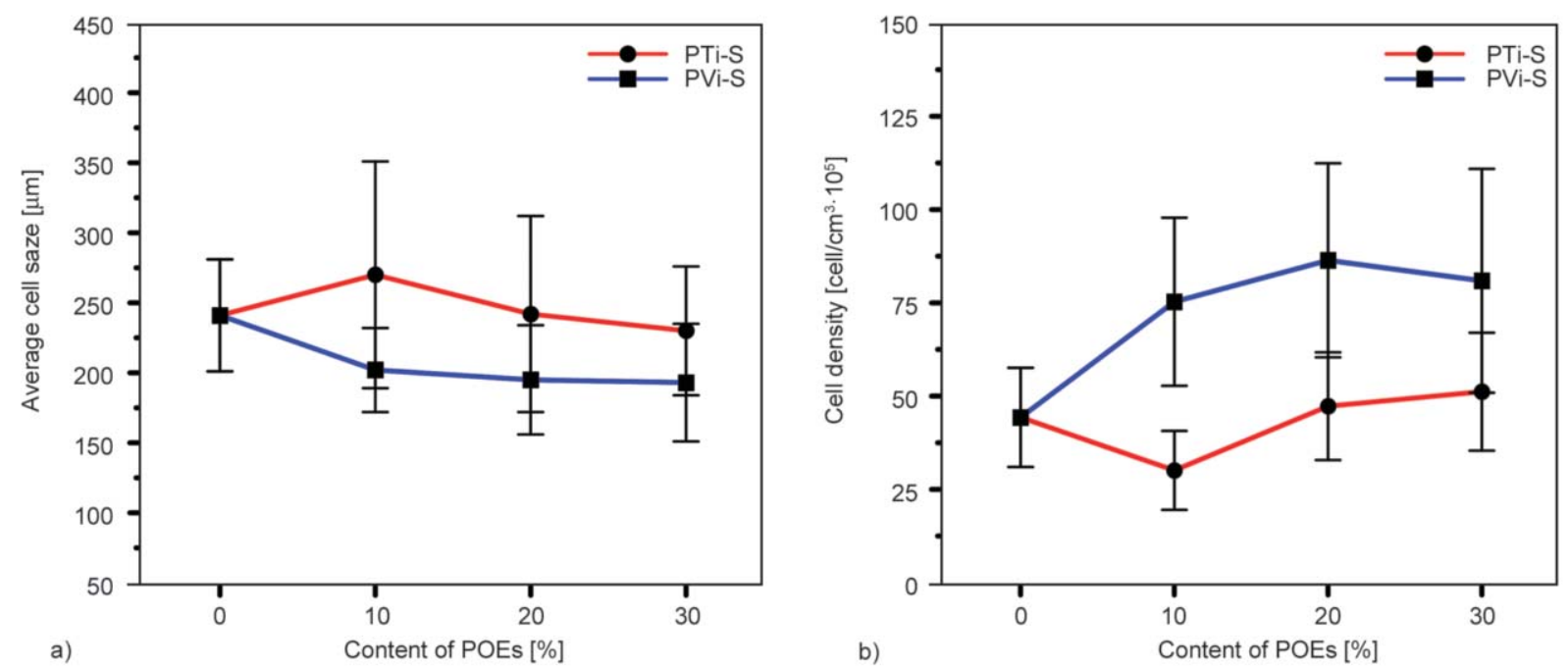

Figure 4. Variation of (a) average cell size and (b) cell density with POE content at different type of POE.

steadily increasing with increased POE percentage, which has resulted in reduced cell size.

Figure 5 displays the SEM images of foam samples produced with azodicarbonamide blowing agent and two types of POE in different percentages. But in the case of azodicarbonamide, due to its nucleation characteristics, the average cell size was significantly smaller [49]. Values for cell size and cell density for samples containing two different types of POE are shown in Figure 6. Generally, it can be stated that cell diameter sizes for samples containing ethylene-based $\mathrm{POE}$ at all concentrations were greater than those of propylene-based POE. The cell diameter was calculated for PT-A and PV-A samples to be in the range

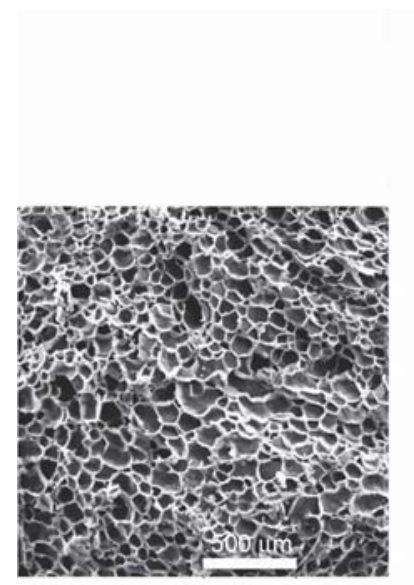

a)

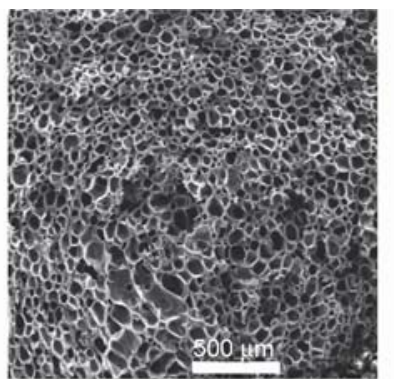

b)

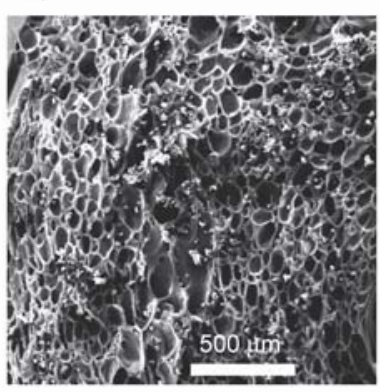

e)

of 35-45 and $28-40 \mu \mathrm{m}$, respectively, which were about 4 to 5 times lower than foams produced with sodium bicarbonate at the same POE type and content. For all foam samples with azodicarbonamide as their blowing agent, the increase in POE concentration caused the average diameter of the cells to decrease slightly, and the shape of the cells was slanted from elliptical to spherical. In other words, at high POE concentrations, it is possible to assume foam surface as a matrix with homogenous distribution of cells. This is not the case for sodium bicarbonate blowing agents, which due to their large size of the cell and their non-uniform distribution, have less applicability. By increasing POE concentration, the cell

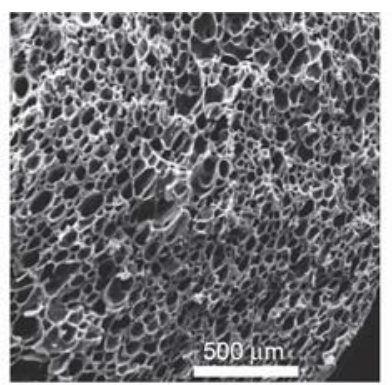

c)

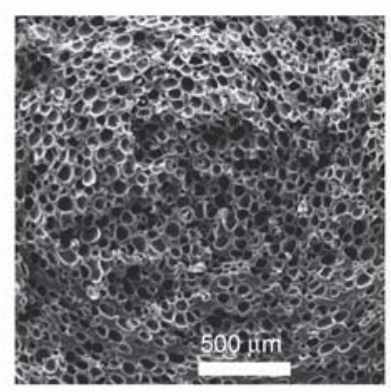

f)

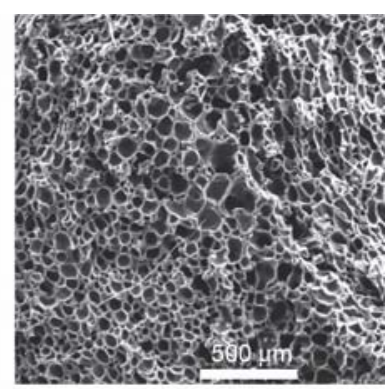

d)

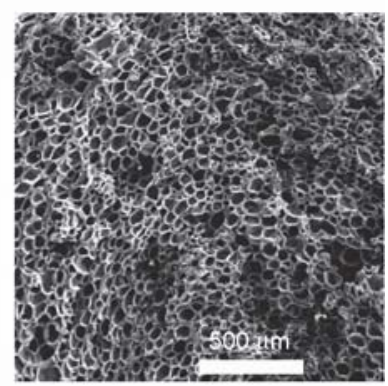

g)

Figure 5. SEM micrographs of fractured surfaces of PP/POE-A Foams; (a) P-A, (b) PT1-A, (c) PT2-A, (d) PT3-A, (e) PV1A, (f) PV2-A and (g) PV3-A. 

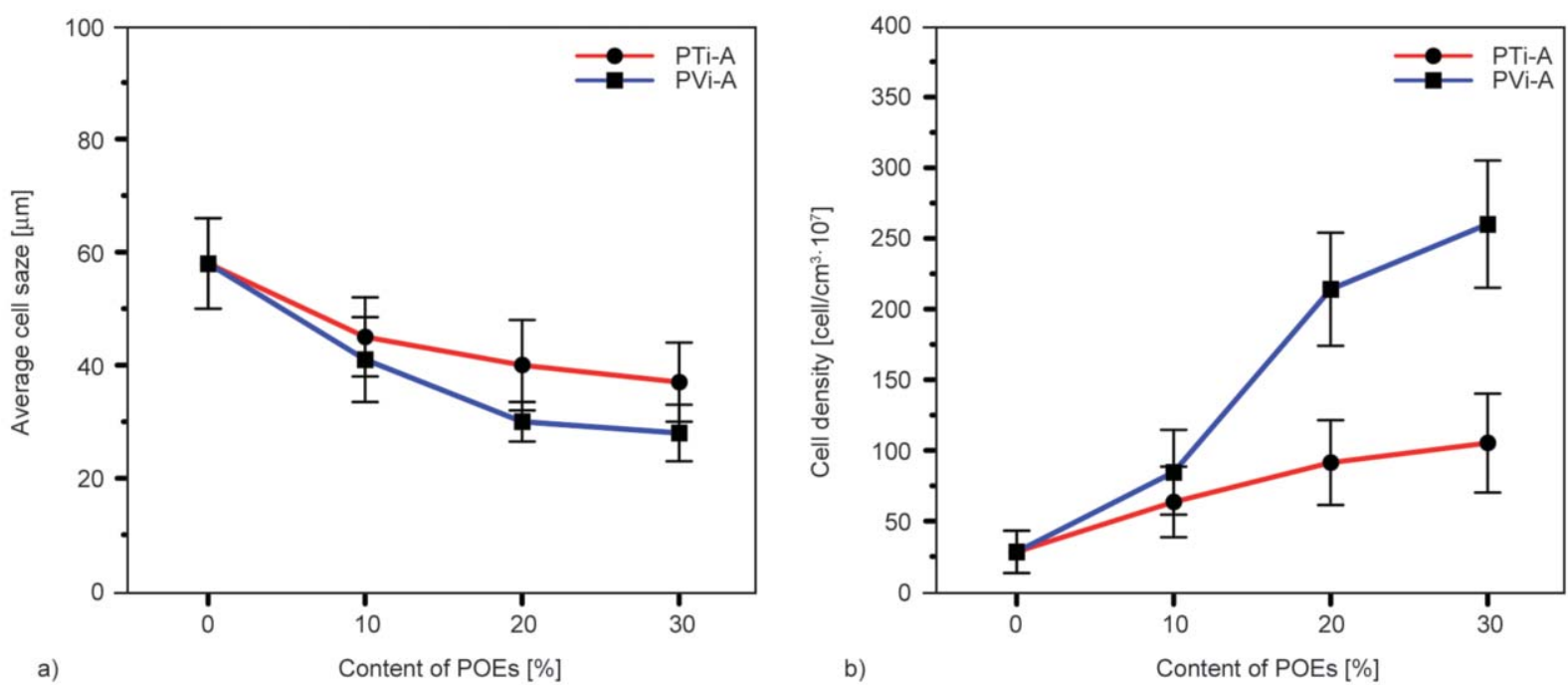

Figure 6. Variation of (a) average cell size and (b) cell density with POE content at different type of POE.

density for PT-A sample has increased incrementally from $6.35 \cdot 10^{7}$ to $10.52 \cdot 10^{7}$ cells $/ \mathrm{cm}^{3}$. PV-A samples have higher cell density than PT-A samples due to their propylene-based $\mathrm{POE}$, and the fine-grain structure compatible with the polypropylene matrix in the foam section [37]. By increasing the concentration of propylene-based POE from 10 to $30 \%$, cell density increased from $8.45 \cdot 10^{7}$ to $2.6 \cdot 10^{8}$ cells $/ \mathrm{cm}^{3}$, and owing to the small change in cell diameter, this significant increase is probably due to the nucleation effect of POE particles in the foam. This indicates more nucleation effects of propylene-based POE compared to ethylene-based POE, similar to that found in foams produced with sodium bicarbonate.

Considering the fact that cell wall thickness is directly correlated to cell size, by calculating wall thickness, it was found that for PP/POE-S samples, cell

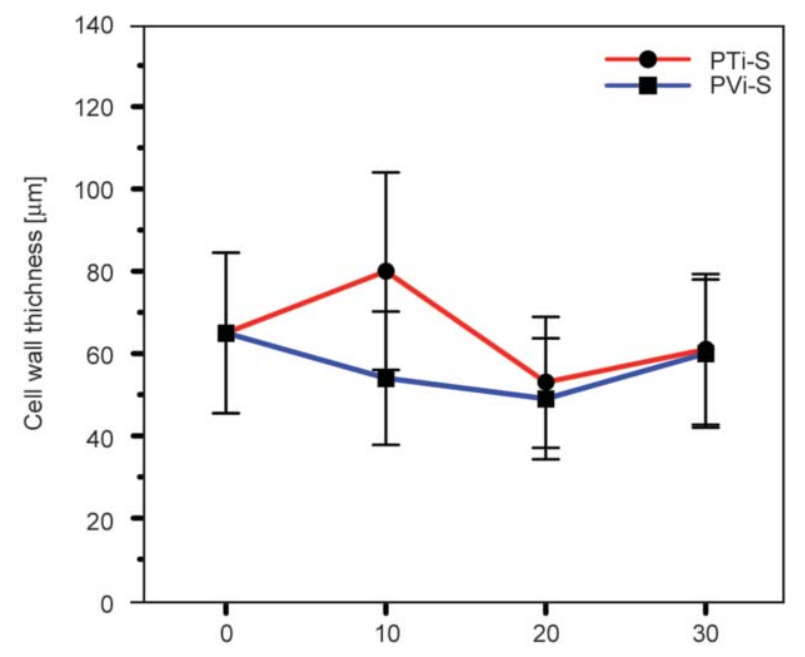

a)

Content of POEs [\%] wall thickness was about $50-80 \mu \mathrm{m}$, whereas for $\mathrm{PP} / \mathrm{POE}-\mathrm{A}$ samples, the same variable was valued at $10-20 \mu \mathrm{m}$. Figure 7 demonstrates the cell wall thickness variation based on the concentration and type of POE for two blowing agents.

It was observed that with the addition of POE, a distinct decrease in the cell wall thickness occurred, and this reduction trend continued to 20\% POE concentration. Then by increasing the POE concentration up to $30 \%$, the cell wall thickness increased slightly but its magnitude was much less than the cell wall thickness for neat PP foam samples in both types of blowing agents. As previously mentioned, PT-S samples have larger cell sizes, more asymmetrical distribution and more spacing distance than PV-S. Therefore, at low POE concentrations, the cell wall thickness of PT-S samples was larger than PV-S, but

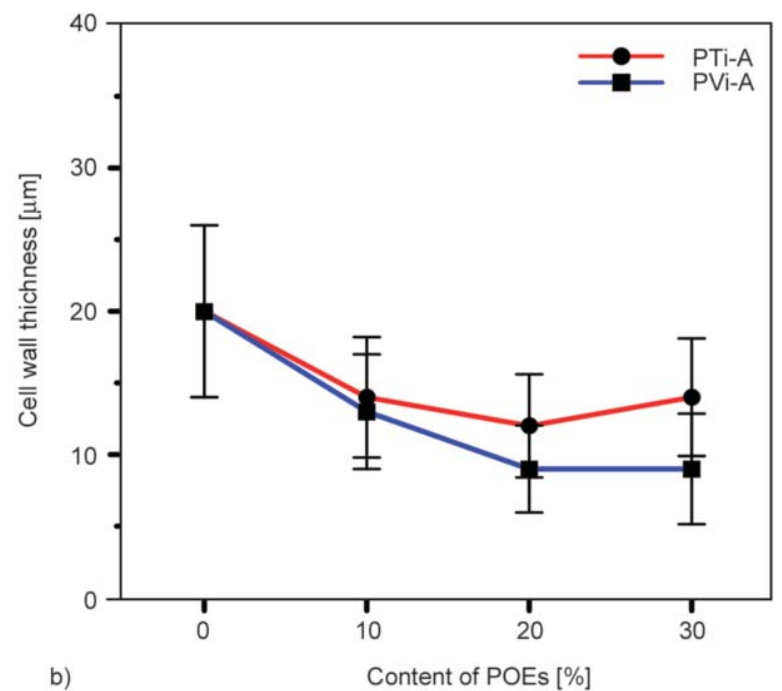

Figure 7. Variation of cell wall thickness of (a) PP/POE-S and (b) PP/POE - a with POE content at different type of POE. 
at higher concentrations, due to the fact that the cellular structure and foamed areas improved for the PT3-S sample, the cell wall thickness decreased as a result and was approximately equal to the PV3-S sample. The lowest cell wall thickness was always observed in samples of $20 \%$ of POE. For further examination, the SEM images of POE particles inside the bubbles of these samples are demonstrated in Figure 8. For better observation, POE phase was extracted from the cell walls by etching with n-pentane for 8 hours. It was observed that samples with the azodicarbonamide foaming agent and propylenebased POE had smaller POE particles along with a more uniform particle distribution.

According to previous studies on the blends of these compounds, the particle size for the POE of the propylene-base was smaller in size due to its compatibility with the PP matrix compared with the ethylene-based

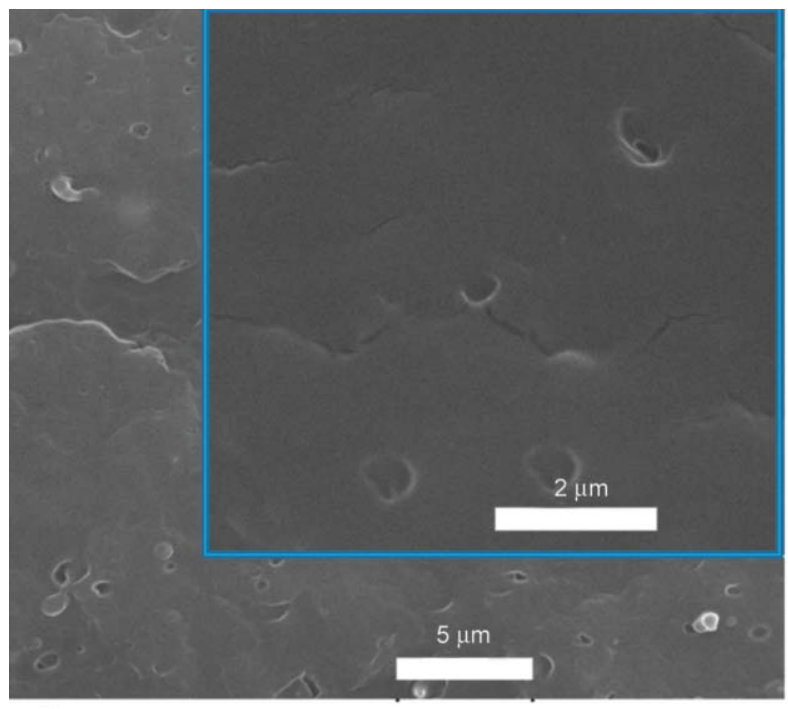

a)

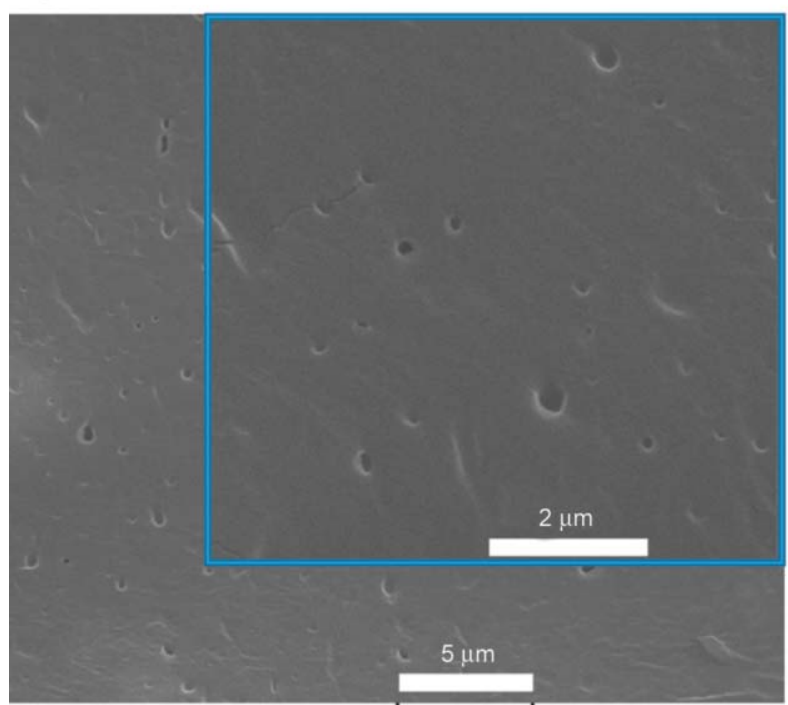

c)
POE [37]. But in the foam mode, these sizes are more close to each other and for samples with a $20 \%$ of POE concentration was obtained about $200 \mathrm{~nm}$. But in terms of particle shape, PV foam samples were irregular in shape, while the particle shape of PT foam samples was spherical. It seems that the formation of irregular shape has occurred due to the phenomenon of bubble growth. Due to the fact that the shape of the bubbles was not spherical, so the dispersed particles of the POE were also irregular. This irregularity is greater for propylene-base POE, which produced smaller particles.

\subsection{Impact strength}

\subsubsection{Effect of type and concentration of $P O E$} By varying the POE type, POE concentration and blowing agent type, different foam morphologies were obtained. The main goal of this paper was to

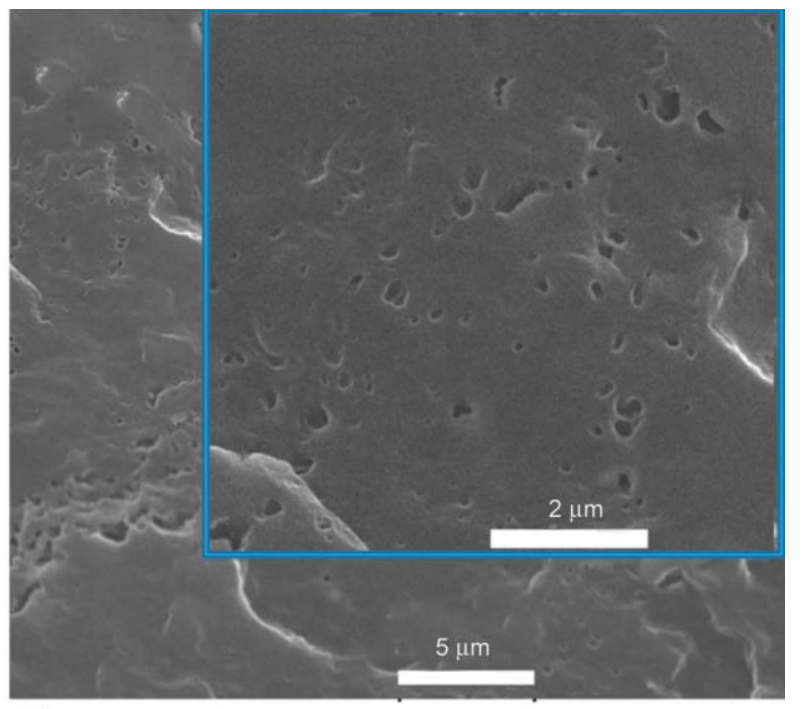

b)

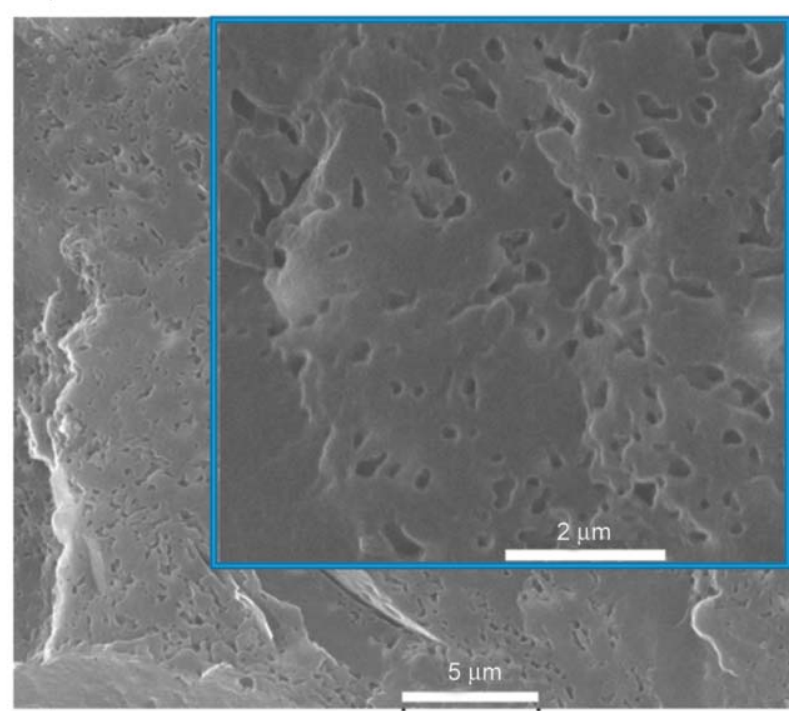

d)

Figure 8. SEM micrographs of fractured surfaces of cell walls; (a) PT2-S, (b) PV2-S, (c) PT2-A and (d) PV2-A. 


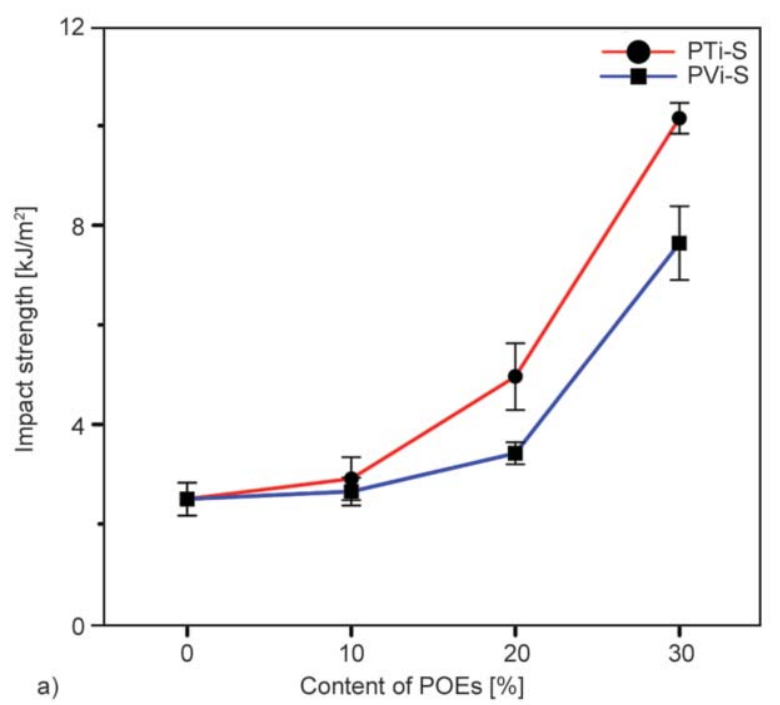

Figure 9. Variation of impact strength of foams produced by of POE.

find that how much the cellular structure affects the impact strength of foams? Figure 9 depicts the impact strength of the foam samples along with the two foaming agents with increased concentrations of POE. The impact strength for neat P-S and P-A foam samples were the same and about $2.50 \mathrm{~kJ} / \mathrm{m}^{2}$. The impact strength of polypropylene foam in all samples increased with increasing POE concentration due to toughening effect of POE phase.

In addition, ethylene-based POE foams had slightly higher impact strength than polypropylene-based POE foams at high POE weight percentages. The type of blowing agent was also effective on the impact strength of the foam. In samples containing 30\% of POE, the foam produced with sodium bicarbonate (PT3-S and PV3-S) had an impact strength of 10.15 and $7.65 \mathrm{~kJ} / \mathrm{m}^{2}$, respectively, while foams produced with azodicarbonamide (PT3-A and PV3-A) had an impact strength of 8.15 and $6.75 \mathrm{~kJ} / \mathrm{m}^{2}$, respectively. The foams with the same POE type and concentration, but different blowing agent, made different impact strength. This revealed that the foam structure affected the impact strength. Foam density, cell structure, cell wall thickness and POE percentage can all affect the impact strength of the foam. In order to understand the contribution of each factor, the impact strength of the foams plotted against each of the probable effective factor.

\subsubsection{Effect of foam density on the impact strength}

Figure 10 demonstrates the impact strength in term the density of foam for PP/POE-S and PP/POE-A

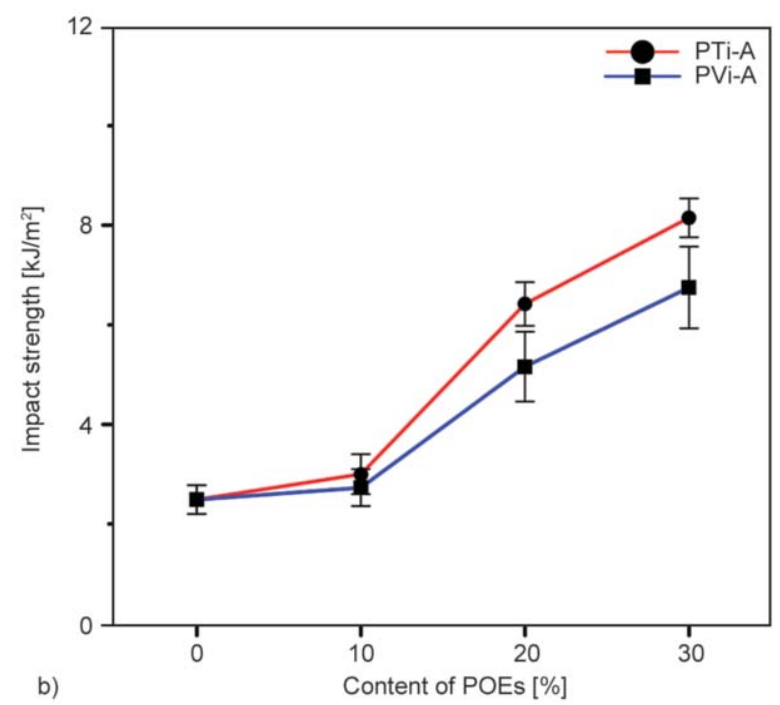

(a) SB and (b) ADC with various POE content at different type

samples. It was observed that the density of the samples was in the range of 290 to $420 \mathrm{~kg} / \mathrm{m}^{3}$, but the impact strength of the blend samples was 4 times higher than the neat foam samples. It was observed from the samples with similar elastomer percentages that the higher the density of the foam usually has higher impact strength. This seems natural due to the higher proportion of the polymer that can absorb energy in higher density of foams, yet in some cases there was an exception. For example, the PT3-S sample has a lower density than PT3-A, but its impact strength is higher. Also, in some samples, changes in the density did not alter impact strength significantly, while in other samples, a significant change was observed. This indicates that foam density is not the single effective parameter on the impact strength

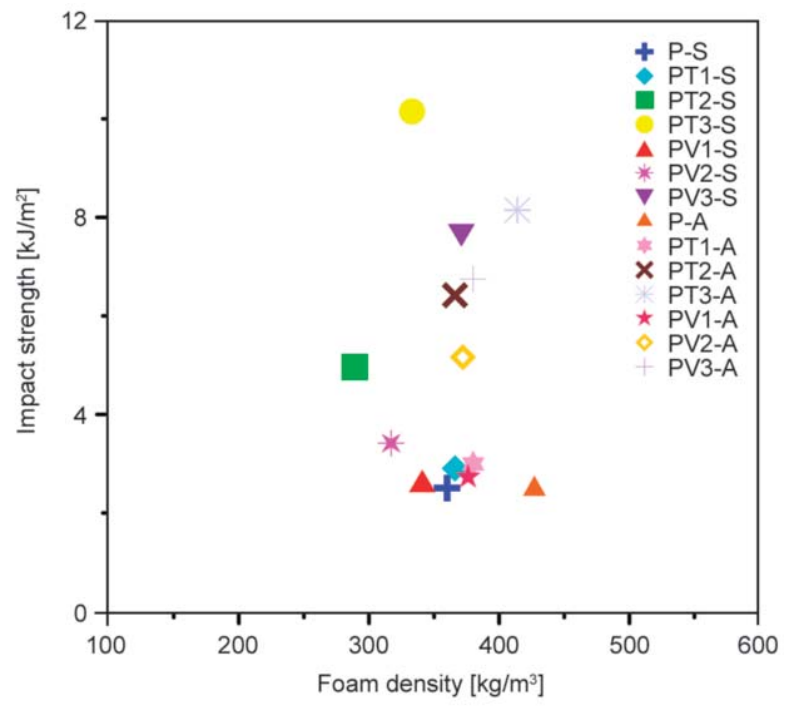

Figure 10. Variation of impact strength of samples with their foam densities. 
and the foam structure can also affect the impact strength. To eliminate the effect of the variation of density, the specific impact strength (impact strength to density ratio) has been used hereafter.

\subsubsection{Effect of cellular parameters on the impact strength}

Some researchers have advocated the effect of cell size and the thickness of the wall on the impact strength [50]. Therefore, this study aims to investigate the effect of the cell wall thickness and fracture cross section in the state of the impact test, from which new results were obtained. Figure 11 illustrates the extent of change in the impact strength versus the cell wall thickness for each type of blowing agents for the same POE at different concentrations.

It was witnessed that for neat PP foam, with a change in the blowing agent from azodicarbonamide, cell wall thickness increased from 20 to $65 \mu \mathrm{m}$, yet the impact strength did not change much. In foam blend samples up to $20 \%$ of POE, the change in cell wall thickness in the range of 20 to $80 \mu \mathrm{m}$ did not have much effect. By increasing the concentration of POE to $30 \%$, in PV3 foam sample, an increase in the cell wall thickness from 9 to $60 \mu \mathrm{m}$ yielded an increase of $30 \%$ in the impact strength. For the PT3 sample, with the same amount of change in the cell wall thickness, the impact strength increased by more than $50 \%$. Analogous results were acquired by observing the impact strength in terms of cell size, shown in Figure 12. Cell size for samples with up to $20 \%$ elastomer has no considerable effect on impact strength. In previous studies on microcrystalline polycarbonate foams,

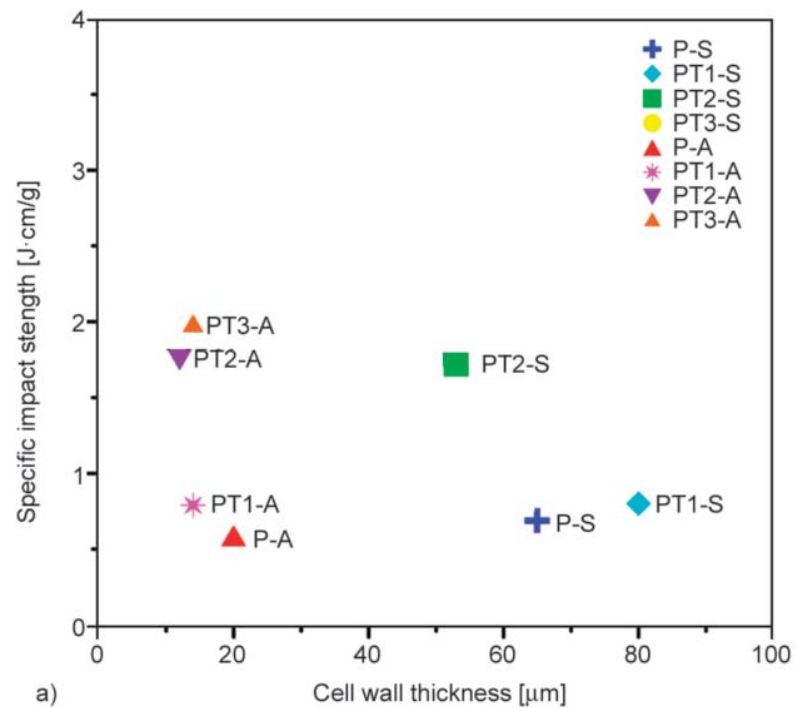

it was reported that reducing cell size would reduce the impact strength [50]. The size of the cells in that study was less than $15 \mu \mathrm{m}$. But in the cell size range of this study, there was no significant difference between the impact strength of the samples and the size of the cells, except in samples containing 30\% elastomer, where the increase in elastomer resulted in a dramatic increase in impact strength. To shed further light on the matter, SEM images from the fracture surface of samples after the impact test are included in Figure 13.

For neat PP foam it was observed that the fracture surface of the cell walls in the P-S has a relatively flat surface. For the thin-walled P-A sample, the wall surface is smooth, and plastic deformation is rarely observed in both samples. While elastomer increased up to $20 \%$, the fracture surface of the sample showed more plastic deformation, but the fracture surface of the cell walls is still almost completely smooth and even. This is visible for two types of elastomer and two types of blowing agents. Increasing the elastomer content by up to $30 \%$ resulted in a rough cell wall fracture of PV3-S and PT3-S, which have higher cell wall thickness. Creating these rough surfaces is very rewarding in absorbing the impact energy and improving the impact strength. When the cell wall thickness is small (PV3-A and PT3-A samples), these rough surfaces were not evident. It appears that the main cause for the increased impact strength by increasing the thickness of the cell wall in 30\% elastomer samples is the increased roughness in cell walls due to the existence of POEs.

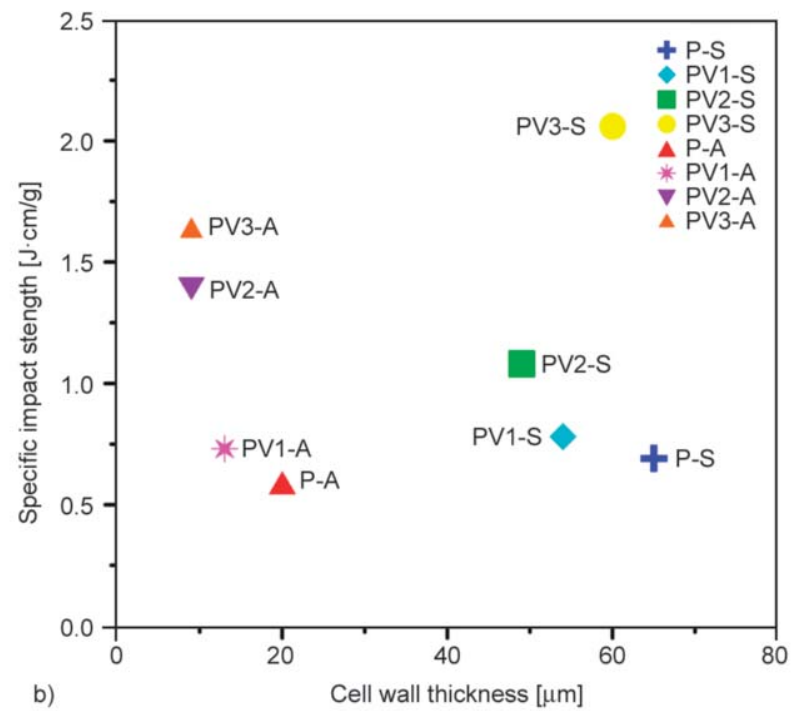

b)

Figure 11. Variation of specific impact strength (a) PTi and (b) PVi foams with cell wall thickness. 

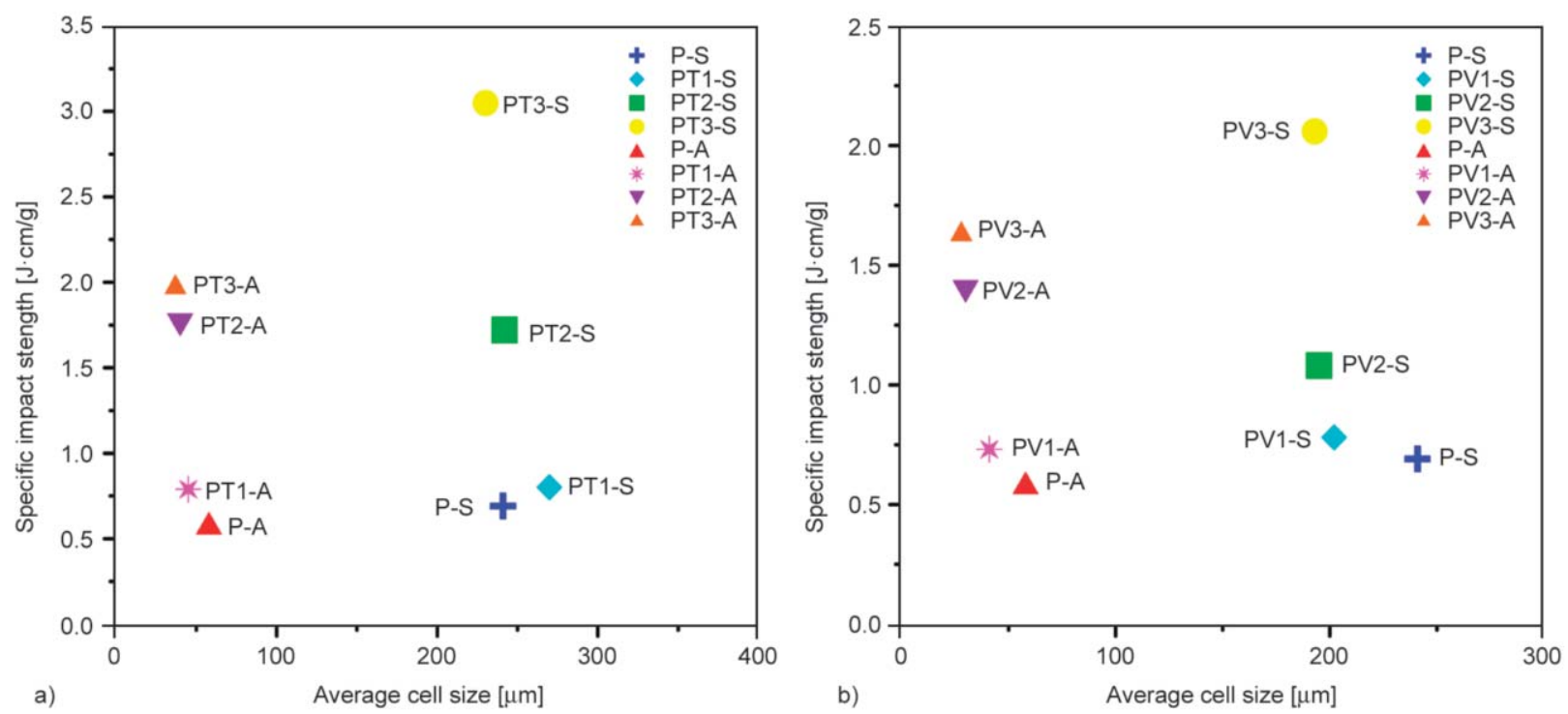

Figure 12. Variation of specific impact strength (a) PTi and (b) PVi foams with cell size.

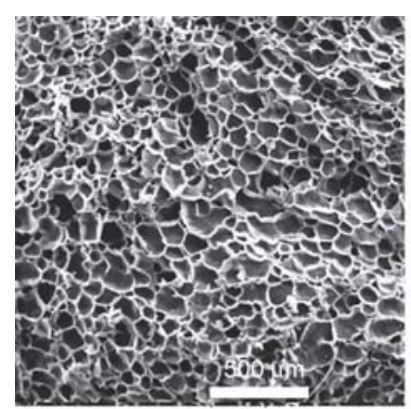

a)

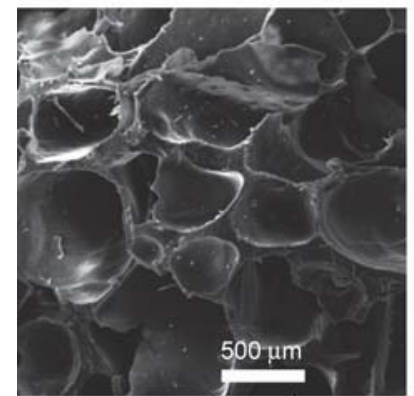

e)

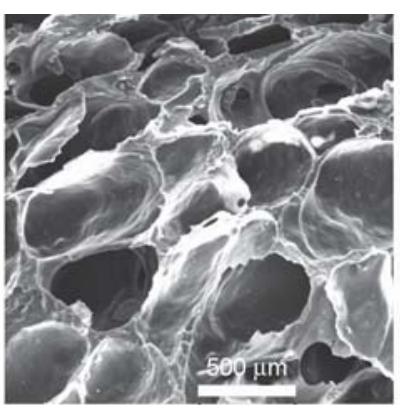

b)

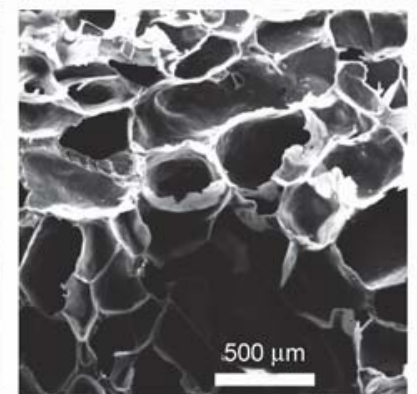

f)

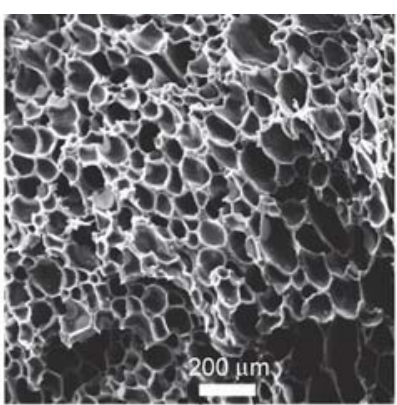

c)

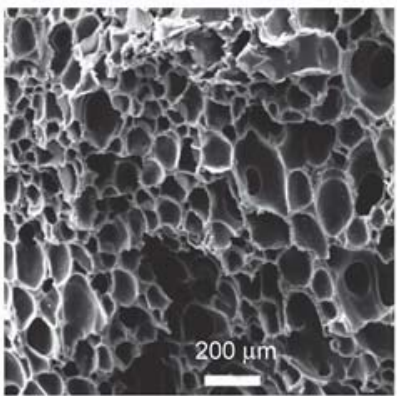

g)

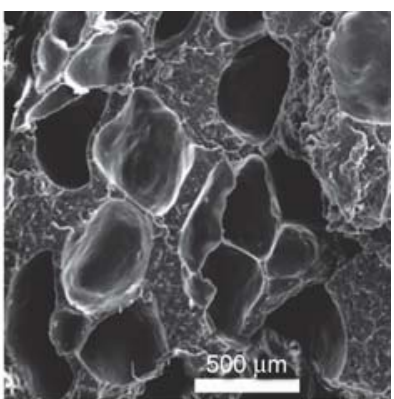

d)

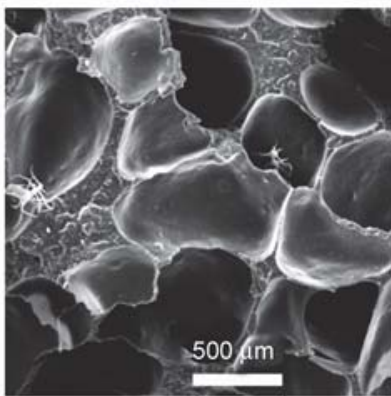

h)

Figure 13. SEM micrographs of fractured surfaces of PP/POE Foams after Impact test; (a) P-A, (b) PT1-S, (c) PV2-A, (d) PV3-S, (e) P-S, (f) PV1-S , (g) PT2-A and (h) PT3-S.

\section{Conclusions}

Polypropylene/polyolefin elastomer blend foams by two different blowing agents and two different types of POEs were produced using the continuous extrusion method. SEM analysis, density, and Charpy impact test were performed for each sample. The density of the foam samples with the sodium bicarbonate blowing agent was lower than that of azodicarbonamide due to higher solubility of $\mathrm{CO}_{2}$ than $\mathrm{N}_{2}$ gas in PP matrix. The highest of expansion ratio was observed in PT2-S. It was observed that by adding elastomer to polypropylene, the size of the cell slightly decreased, but at higher concentrations, the cell size decreased and order of the cellular structure reached to a fitting level. In addition, cells in PV-S and PV-A were always smaller than those of PT-S and PT-A. There was also a significant increase in cell density, especially at high concentrations of the elastomer, to such extent that in the samples with ADC this increase was 13 times higher in the PV3A than P-A sample. Impact strength improved significantly (up to $400 \%$ ) with increasing elastomer concentration. Moreover, it was observed that at high elastomer concentration, the sample with the thicker 
wall thickness has higher impact strength. At a concentration of $30 \%$ percent of elastomer, the fracture cell wall was vastly affected by the incidence of POE particles. Considering the increase in cell wall thickness by changing the blowing agents, a strong increase was observed in the impact strength due to rough fracture mechanism of thicker cell walls.

\section{References}

[1] Benning C. J.: Plastic foams, the physics and chemistry of product performance and process technology. WileyInterscience, New York (1969).

[2] Stevenson J. F.: Innovation in polymer processing. Hanser, Munich (1996).

[3] Perkowitz S.: Universal foam, exploring the science of nature's most mysterious substance. Anchor Books, New York (2001).

[4] Hilyard N. C., Cunningham A.: Low density cellular plastics; Physical basis of behavior. Springer, Dordrecht (2012).

[5] Buist J. M., Gudgeon H.: Advances in polyurethane technology. Wiley, London (1968).

[6] Throne J. L.: An observation on the Han-Villamizar critical pressure concept in thermoplastic foams. Polymer Engineering and Science, 23, 354-355 (1983). https://doi.org/10.1002/pen.760230610

[7] Klempner D., Frisch K. C.: Handbook of polymeric foams and foam technology. Hanser, Munich (1991).

[8] Lee S. T.: Foam extrusion: Principles and practice. Technomic, Lancaster (2000).

[9] Colton J. S.: The nucleation of microcellular foams in semi crystalline thermoplastics. Materials and Manufacturing Processes, 4, 253-262 (1989).

https://doi.org/10.1080/10426918908956288

[10] Harper C. A.: Modern plastics handbook. McGrawHill, New York (1994).

[11] Karger-Kocsis J.: Polypropylene: Structure, blends and composites; Vol. 2 - Copolymers and blends. Chapman and Hall, London (1995).

[12] Shau-Tarng L., Park C. B., Ramesh N. S.: Polymeric foams; Science and technology. Taylor and Francis, New York (2007).

[13] Park C. B., Cheung L. K.: A study of cell nucleation in the extrusion of polypropylene foams. Polymer Engineering and Science, 37, 1-10 (1997).

https://doi.org/10.1002/pen.11639

[14] Jahani Y., Barikani M.: Effect of side chain branched PP, EPDM and HDPE as a third component on melt extensional behaviour of ternary blends. Iranian Polymer Journal, 14, 693-704 (2005).

[15] Xu Z. J., Xue P., He J.: Effects of formulations and processing parameters on foam morphologies in the direct extrusion foaming of polypropylene using a single-screw extruder. Journal of Cellular Plastics, 41, 169-185 (2005). https://doi.org/10.1177/0021955X05051740
[16] Jurczuk K., Galeski A., Morawiec J.: Effect of poly (tetrafluoroethylene) nanofibers on foaming behavior of linear and branched polypropylenes. European Polymer Journal, 88, 171-182 (2017).

https://doi.org/10.1016/j.eurpolymj.2017.01.024

[17] Bhattacharya S., Gupta R. K., Jollands M., Bhattacharya S. N.: Foaming behavior of high-melt strength polypropylene/clay nanocomposites. Polymer Engineering and Science, 49, 2070-2084 (2009). https://doi.org/10.1002/pen.21343

[18] Zhao J., Zhao Q., Wang L., Wang C., Guo B., Park C. B., Wang G.: Development of high thermal insulation and compressive strength BPP foams using mold-opening foam injection molding with in-situ fibrillated PTFE fibers. European Polymer Journal, 98, 1-10 (2018). https://doi.org/10.1016/j.eurpolymj.2017.11.001

[19] Lee Y-D., Wang L-F.: Properties of polypropylene structural foam crosslinked by vinyltrimethoxy silane. Journal of Applied Polymer Science, 32, 4639-4647 (1986). https://doi.org/10.1002/app.1986.070320428

[20] Weng W., Hu W., Dekmezian A. H., Ruff C. J.: Long chain branched isotactic polypropylene. Macromolecules, 35, 3838-3843 (2002). https://doi.org/10.1021/ma020050j

[21] Ye Z., AlObaidi Y., Zhu S.: Synthesis and rheological properties of long-chain-branched isotactic polypropylenes prepared by copolymerization of propylene and nonconjugated dienes. Industrial and Engineering Chemistry Research, 43, 2860-2870 (2004).

https://doi.org/10.1021/ie0499660

[22] Li S., Xiao M., Guan Y., Wei D., Xiao H., Zheng A.: A novel strategy for the preparation of long chain branching polypropylene and the investigation on foamability and rheology. European Polymer Journal, 48, 362-371 (2012). https://doi.org/10.1016/j.eurpolymj.2011.11.015

[23] Gotsis A. D., Zeevenhoven B. L. F., Hogt A. H.: The effect of long chain branching on the processability of polypropylene in thermoforming. Polymer Engineering and Science, 44, 973-982 (2004).

https://doi.org/10.1002/pen.20089

[24] Naguib H. E., Park C. B., Panzer U., Reichelt N.: Strategies for achieving ultra low-density polypropylene foams. Polymer Engineering and Science, 42, 1481-1492 (2002). https://doi.org/10.1002/pen.11045

[25] Fasihi M., Asgari A., Bayat H.: The simultaneous effect of nucleating and blowing agents on the cellular structure of polypropylene foamed via the extrusion process. e-Polymers, 16, 235-241 (2016). https://doi.org/10.1515/epoly-2016-0033

[26] Avalle M., Belingardi G., Montanini R.: Characterization of polymeric structural foams under compressive impact loading by means of energy-absorption diagram. International Journal of Impact Engineering, 25, 455472 (2001). https://doi.org/10.1016/S0734-743X(00)00060-9 
[27] Karger-Kocsis J., Kalló A., Kuleznev V. N.: Phase structure of impact-modified polypropylene blends. Polymer Engineering and Science, 25, 279-286 (1984). https://doi.org/10.1016/0032-3861(84)90337-9

[28] van der Wal A., Mulder J. J., Oderkerk J., Gaymans. R. J.: Polypropylene-rubber blends: 1 . The effect of the matrix properties on the impact behaviour. Polymer, 39, 6781-6787 (1998).

https://doi.org/10.1016/S0032-3861(98)00170-0

[29] D'Orazio L., Cecchin G.: Isotactic polypropylene/ethylene-co-propylene blends: Effects of composition on rheology, morphology and properties of injection moulded samples. Polymer, 42, 2675-2684 (2001). https://doi.org/10.1016/S0032-3861(00)00631-5

[30] Yeh J-T., Lin S-C.: Optimized processing conditions for the preparation of dynamically vulcanized EPDM/PP thermoplastic elastomers containing PP resins of various melt indexes. Journal of Applied Polymer Science, 114, 2806-2815 (2009). https://doi.org/10.1002/app.30865

[31] Grein C., Gahleitner M., Bernreitner K.: Mechanical and optical effects of elastomer interaction in polypropylene modification: Ethylene-propylene rubber, poly(ethylene-co-octene) and styrene-butadiene elastomers. Express Polymer Letters, 6, 688-696 (2012). https://doi.org/10.3144/expresspolymlett.2012.74

[32] Yamaguchi M., Miyata H., Nitta K-H.: Compatibility of binary blends of polypropylene with ethylene- $\alpha$ olefin copolymer. Journal of Applied Polymer Science, 62, 87-97 (1996).

https://doi.org/10.1002/(SICI)10974628(19961003)62:1<87::AID-APP12>3.0.CO;2-5

[33] Thomann Y., Suhm J., Thomann R., Bar G., Maier R-D., Mülhaupt R.: Investigation of morphologies of one- and two-phase blends of isotactic poly(propene) with random poly(ethene-co-1-butene). Macromolecules, 31, 5441-5449 (1998).

https://doi.org/10.1021/ma980179m

[34] Mäder D., Thomann Y., Suhm J., Mülhaupt R.: Influence of comonomer incorporation on morphology and thermal and mechanical properties of blends based upon isotactic metallocene-polypropene and random ethene/1-butene copolymers. Journal of Applied Polymer Science, 74, 838-848 (1999).

https://doi.org/10.1002/(SICI)10974628(19991024)74:4<838::AID-APP10>3.0.CO;2-L

[35] Tsou A. H., Lyon M. K., Chapman B. R., Datta S.: Elastic properties of cast films from propylene elastomers. Journal of Applied Polymer Science, 107, 1362-1372 (2008). https://doi.org/10.1002/app.27184

[36] Chen X-H., Ma G-Q., Li J-Q., Jiang S-C., Yuan X-B., Sheng J.: Study on morphology evolution and fractal character of the miscible blend between isotactic polypropylene and copolymer of ethylene and propylene. Polymer, 50, 3347-3360 (2009).

https://doi.org/10.1016/j.polymer.2009.04.069
[37] Fasihi M., Mansouri H.: Effect of rubber interparticle distance distribution on toughening behavior of thermoplastic polyolefin elastomer toughened polypropylene. Journal of Applied Polymer Science, 133, 44067/144067/9 (2016). https://doi.org/10.1002/app.44068

[38] Kim S. G., Leung S. N., Park C. B., Sain M.: The effect of dispersed elastomer particle size on heterogeneous nucleation of TPO with $\mathrm{N}_{2}$ foaming. Chemical Engineering Science, 66, 3675-3686 (2011).

https://doi.org/10.1016/j.ces.2011.05.003

[39] Tammaro D., Iannace S., Maio E. D.: Insight into bubble nucleation at high-pressure drop rate. Journal of Cellular Plastics, 53, 551-560 (2017).

https://doi.org/10.1177/0021955X17695094

[40] Entezam M., Abbasi M., Ahmadi M.: Theoretical correlation of linear and non-linear rheological symptoms of long-chain branching in polyethylenes irradiated by electron beam at relatively low doses. Rheologica Acta, 56, 729-742 (2017). https://doi.org/10.1007/s00397-017-1029-9

[41] Shieh Y-T., Su J-H., Manivannan G., Lee P. H. C., Sawan S. P., Spall W. D.: Interaction of supercritical carbon dioxide with polymers. I. Crystalline polymers. Journal of Applied Polymer Science, 59, 695-705 (1996).

https://doi.org/10.1002/(SICI)10974628(19960124)59:4<695::AID-APP15>3.0.CO;2-P

[42] Shieh Y-T., Su J-H., Manivannan G., Lee P. H. C., Sawan S. P., Spall W. D.: Interaction of supercritical carbon dioxide with polymers. II. Amorphous polymers. Journal of Applied Polymer Science, 59, 707-717 (1996). https://doi.org/10.1002/(SICI)10974628(19960124)59:4<707::AID-APP16>3.0.CO;2-M

[43] Sato Y., Fujiwara K., Takikawa T., Sumarno, Takishima S., Masuoka H.: Solubilities and diffusion coefficients of carbon dioxide and nitrogen in polypropylene, highdensity polyethylene, and polystyrene under high pressures and temperatures. Fluid Phase Equilibria, 162, 261-276 (1999).

https://doi.org/10.1016/S0378-3812(99)00217-4

[44] Naguib H. E., Park C. B., Reichelt N.: Fundamental foaming mechanisms governing the volume expansion of extruded polypropylene foams. Journal of Applied Polymer Science, 91, 2661-2668 (2004). https://doi.org/10.1002/app.13448

[45] Nam P. H., Maiti P., Okamoto M., Kotaka T., Nakayama T., Takada M., Ohshima M., Usuki A., Hasegawa N., Okamoto H.: Foam processing and cellular structure of polypropylene/clay nanocomposites. Polymer Engineering and Science, 42, 1907-1918 (2002). https://doi.org/10.1002/pen.11083

[46] Bhatti A. S., Dollimore D., Goddard R. J., Donnell G. O.: The thermal decomposition of azodicarbonamide. Thermochimica Acta, 76, 63-77 (1984). https://doi.org/10.1016/0040-6031(84)87004-5 
[47] Barall E. M., Rogers L. B.: Differential thermal analysis of the decomposition of sodium bicarbonate and its simple double salts. Journal of Inorganic and Nuclear Chemistry, 28, 41-51 (1966).

https://doi.org/10.1016/0022-1902(66)80226-9

[48] Li G., Gunkel F., Wang J., Park C. B.: Altstädt V.: Solubility measurements of $\mathrm{N}_{2}$ and $\mathrm{CO}_{2}$ in polypropylene and ethene/octene copolymer. Journal of Applied Polymer Science, 103, 2945-2953 (2007).

https://doi.org/10.1002/app.25163
[49] Yang H-H., Han C. D.: The effect of nucleating agents on the foam extrusion characteristics. Journal of Applied Polymer Science, 29, 4465-4470 (1984). https://doi.org/10.1002/app.1984.070291281

[50] Barlow C., Kumar V., Flinn B., Bordia R. K., Weller J.: Impact strength of high density solid-state microcellular polycarbonate foams. Journal of Engineering Materials and Technology, 123, 229-233 (2001).

https://doi.org/10.1115/1.1339004 